\title{
Social Inequality among the Female Merchants of Ethnic Malay and Chinese
}

\author{
Eraskaita Ginting 1,* (D), and Yusnaini Yusnaini ${ }^{2}$ \\ ${ }^{1}$ Department of Communication Studies, Faculty of Social and Political Sciences, \\ Raden Fatah State Islamic University of Palembang, 30126, Palembang, Indonesia \\ 2 Department of Communication Studies, Faculty of Social and Political Sciences, \\ Nurdin Hamzah Institute of Social and Political Sciences, 36129, Jambi, Indonesia \\ * Corresponding Author: eraskaitaginting_uin@radenfatah.ac.id
}

\section{ARTICLE INFO}

\section{Publication Info:}

Research Article

How to cite:

Ginting, E., E Yusnaini, Y.

(2020). Social Inequality among the Female Merchants of Ethnic

Malay and Chinese. Society, 8(1), $1-12$.

DOI : 10.33019/society.v8i1.126

Copyright (C) 2020. Owned by Author(s), published by Society

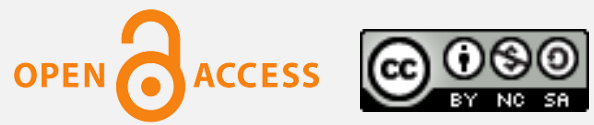

This is an open-access article.

\section{License: Attribution-}

NonCommercial-ShareAlike (CC BY-NC-SA)

Received: November 19, 2019; Accepted: February 26, 2020; Published: March 13, 2020;

\begin{abstract}
People in Jambi city assume that Pasar Hong Kong, a traditional market located in Jelutung sub-district, is "a Chinese market", even some areas in the city of Jambi such as Jelutung, Koni, and Talang Banjar are dominated by the ethnic of Chinese. This research aims to explore how social inequality that occurs due to the advantages and disadvantages of an ethnic group so that it can affect individual attitudes that damage social capital. This research uses a case study approach with in-depth interviews and literature study as data collection techniques. The subjects of this study were ethnic Malay and Chinese female merchants in Pasar Hong Kong, Jambi city, Indonesia. This research found that social inequalities that occur among the female merchants of ethnic Malay and Chinese in Pasar Hongkong occur naturally, where both merchants and buyers have a high tolerance when interacting. Although sometimes there are differences in attitude when the merchants serve different ethnic buyers. The involvement of traditional leaders in managing social inequalities is very important due to the lack of assimilation among ethnic Malay and Chinese.
\end{abstract}

Copyright (C) 2020. Owned by Author(s), published by Society. This is an open-access article under the CC-BY-NC-SA license. https://doi.org/10.33019/society.v8i1.126

Keywords: Chinese; Ethnic; Female; Malay; Merchants; Social Inequality 


\section{Introduction}

The ethnic Chinese are one of the non-native groups who migrated to Indonesia. Chinese people entered and subsequently spread to all areas of Indonesia, the large waves of migration from Malaysia and Mainland China. Jambi became one of the destinations of the ethnic Chinese in spreading, settling and continuing their lives. According to population census data in 2015, the population of Jambi Province was 3,397,164 people, and 42,124 people were ethnic Chinese. Ethnic Chinese are scattered in almost all areas of Jambi Province, including in Jelutung subdistrict. Jelutung sub-district had the highest population density in Jambi city with an average population density of $7,914 / \mathrm{km}^{2}$. Cempaka Putih urban village had the highest population density in Jelutung sub-district $\left(10,443 / \mathrm{km}^{2}\right)$, while Lebak Bandung urban village had the lowest population density $\left(5,111 / \mathrm{km}^{2}\right)$. The total population in Jelutung sub-district according to BPS in 2015 was 14,728 people (Badan Pusat Statistik Provinsi Jambi, 2016).

With a large number of ethnic Chinese, communication and interaction between ethnic Malay and Chinese is a routine of daily life. However, many differences were found in the daily communication of the two ethnic groups due to different cultural backgrounds and cultural values, which then influenced the attitudes and behavior of each ethnic group.

Ethnic Chinese merchants with their unique models have been studied by several researchers. Reinhard (2014) focused on the varied work ethics possessed by ethnic Chinese merchants, so this research wanted to see more clearly how the work ethic depicted on ethnic Chinese merchants. In this research, the target subjects are all ethnic Chinese merchants in Jakarta. The results showed that as many as $28.1 \%$ of ethnic Chinese merchants were in the medium category, but tended to below. However, $24.2 \%$ and $22.9 \%$ were in the low and very low categories. This research also concluded that the work ethic is a commitment; both in the form of attitudes, behavior, character, and ethics of a person at work, there are values and importance of hard work as a totality of a person to achieve maximum results.

A similar study conducted by Efnita et al., (2007) focused on how adversity quotient is in ethnic Chinese merchants and the factors that influence adversity quotient in ethnic Chinese merchants. This research conducts an inventory of how ethnic Chinese merchants fight the difficulties and live in trade competition. This research also briefly explained the ability of individuals in dealing with problems or difficulties by running four dimensions including 1) control, 2) ownership, 3) reach, and 4) endurance. Factors that influence adversity quotient in ethnic Chinese merchants are 1) religious factors, which make the subject more calm and patient in dealing with problems; 2) the existence of internal motivation (strong will in self), which makes the subject always optimistic; 3) the existence of confidence in self-ability; 4) modeling factors from parents; 5) environmental conditions which require the subject to survive; and 6) self-actualization factors, which make the subject continue to develop their potential. But some subjects are more motivated by the needs and satisfaction of life, not overly ambitious in material terms, only trying to the maximum.

The management of social inequality among the female merchants of ethnic Malay and Chinese at Pasar Hong Kong in Jambi city would be interesting to research as a further reference from the two types of research above. This is quite argumentative because until now the strengths and weaknesses of both ethnic groups still influence individual attitudes and behavior. For example, differences in treatment, both verbally and nonverbally, are often found when ethnic Malay and Chinese communicate and interact.

Different views in looking at other groups or ethnicities in the communication process often lead to difficult tendencies to communicate among cultures and can affect interactions among various ethnicities. This arises because they tend to give symbols to others even though only at

Copyright (C 2020. Owned by Author(s), published by Society. This is an open-access article under the CC-BY-NC-SA license. https://doi.org/10.33019/society.v8i1.126 
the initial meeting. Making symbols in others greatly influences and controls them in dealing with that person. Making symbols can be misleading and dangerous if they make superficial and too easy estimates of people they don't know well. This is one of the reasons why so many relationships with people from different ethnicities are not so close. Because of a bad experience from one individual from one ethnic group, all members of that ethnic group will make a 'generalization' to individuals from different ethnicities.

Discriminatory, stereotypical and prejudiced behavior towards other ethnicities is a picture that reflects that the relationship between the two ethnic groups is still not harmonious so it needs to be improved in terms of communication. Traditional leaders are important and strategic elements as a bridge and facilitator in facilitating the two ethnic groups. So far, the involvement of traditional leaders has not been maximized. The involvement of traditional leaders is expected to help prevent the behavior and views that are still negative of any problems that occur among ethnic Malay and Chinese.

Ethnic Chinese in the trade sector is realized or not has contributed a variety of Indonesian economic activities, both positive and negative. Pasar Hong Kong is one of the markets that have long existed in the city of Jambi. This market is commonly called the Chinese market because almost all of the sellers and buyers are ethnic Chinese. Like other traditional markets, Pasar Hong Kong sells a variety of daily necessities such as vegetables, side dishes, fruits, food ingredients, and ethnic Chinese prayer equipment. Later, Pasar Hong Kong was not only dominated by Chinese sellers and buyers, but there were also ethnic Jambi Malay who were selling and buying in this market.

Although there is a mixture of ethnic Chinese merchants and Malay at the market, outside of trading activities, there are restrictions on ethnic groups. Ethnic Chinese in their daily activities tend to prefer to associate with fellow ethnic groups, and vice versa. Social relations among ethnic Malay merchants and Chinese at Pasar Hong Kong are reflected in several activities such as "social relations in the market" and "outside the market". In general, they can coexist well, both economically benefiting each other. However, ethnic stereotypes between the two still exist and are increasingly developing in Jambi society which is quite influential in the social relations of the two ethnicities in daily life.

Differences in assumptions, from the viewpoint of buyers to female merchants of ethnic Chinese and Malay will ultimately lead to the dynamics of social inequality that disrupted the process of buying and selling at Pasar Hong Kong. This research provides a formulation of the management of potential social inequalities that are vulnerable to conflict in the continuation of the buying and selling process among the ethnic Malay and Chinese through the Jambi community base.

The purpose of this research is classified into two characteristics, firstly, academic which consists of a) The dynamics of social inequality of female merchants of ethnic Jambi Malay and Chinese at Pasar Hong Kong in Jambi city; b) To find out the involvement of traditional leaders in overcoming social inequalities of female merchants of ethnic Jambi Malay and Chinese. Secondly, practical, giving consideration and input to the Jambi city government, Malay community leaders and Chinese community leaders related to the management of potential social inequalities that have the potential to cause conflicts among the two ethnicities through community bases.

Many benefits can be obtained from this research, such as a) theoretically, contributing to the development of ethnic social inequality analysis studies; multiculturalism, adding discourse and references related to symbolic interaction theory and case study approaches. Contribute to researchers to conduct further studies or as a material for comparison about inter-ethnic 
communication, especially conflict control through effective communication. b) Practically, for educational institutions, this is additional capital for prospective educational developers, especially in the field of intercultural communication analysis through a case study approach and symbolic interaction theory. For the government, especially the community of Malays and Chinese, this research can be used as a projection in the management of social inequalities in intercultural and interethnic communication.

\section{Literature Review}

Several studies on ethnicity have been widely studied by other researchers, one of which was conducted by Ilyas Lampe and Haslinda Anriani who examined stereotypes, prejudices and interethnic dynamics. This research explained that ethnic identity in its implementation can lead to the emergence of stereotypes and prejudices and further this ethnic identity can lead to violent conflict. This research begins with the existence of an ethnic identity that emerges between indigenous and migrant ethnic groups, namely the Kaili and Bugis ethnic groups in the city of Palu. The results of this research note that negative and positive stereotypes still appear in both ethnicities. The main cause of the intersection is usually due to economic inequality between residents (Lampe \& Anriani, 2016).

Similar research on ethnicity was also carried out by Lusiana Andriani Lubis who examined the communication between Chinese and Indigenous ethnic cultures in the city of Medan. This research looks at and knows how intercultural communication influences the views of both ethnicities. There are three indicators in this research which include: first, religion or belief; second, values; and third is behavior. The results of this research found that the conversion of religions such as Islam to Christianity would cause changes in religious views as well as intercultural communication that could change the way of viewing Chinese and Indigenous cultural values. The results of this research are also known that intercultural communication encourages individual behavior to be positive (Lubis, 2012). From the two previous types of research above, it can be seen that there are quite big differences with this research, especially in terms of informants and the focus of the research, so that this research has a great opportunity to produce new research.

\section{A. The Values of Ethnic Social Inequality}

In this research, social inequality is a very important concept. The condition of society becomes increasingly unequal due to economic inequality which can damage personal and social well-being and potentially damage the security function in society. Psychosocial factors are one of the factors that can contribute to maintaining this function (Rodriguez-Bailon et al., 2017). The existence of education and technological development, which is increasingly sophisticated, also influences the process of the value of ethnic Jambi Malay and Chinese. Still often found, each ethnic group carries a different cultural background, such as customs, moral norms (social values) and various regulations that can form a social life system that mutually adjusts, and does not appear to impose that their patriarch of values is good and must be used as a reference.

Diversity and differences in place of birth, skin color, language, and religion are primordial realities that a person accepts, not because of the results of his efforts. Likewise, kinship relations and religious beliefs have a significant influence (Lampe \& Anriani, 2017). Differences in ethnic identity sometimes cause stereotypes among ethnic groups. The stereotype is to generalize the impression of an ethnicity. Samovar et al., (2014) explained that stereotypes can eventually hamper communication. The causes are: 1) information that is delivered consistently

Copyright (C 2020. Owned by Author(s), published by Society. This is an open-access article under the CC-BY-NC-SA license. https://doi.org/10.33019/society.v8i1.126 
about what someone believes; 2) Information delivered to an ethnic group as a whole seems to be the same about that ethnic culture; 3) The stereotype is too excessive and generalized; 4) Stereotype is consistent and static because it will continue to be trusted and develop from generation to generation within an ethnic group.

For example, ethnic Chinese often say that from childhood, their parents always reminded them that they had to hang out and make friends with fellow ethnic Chinese, to stay away from racial problems that would come in the future. Parents will be angry if their children make close friends with other ethnic groups, including Jambi Malay and accuse their children of damaging the family's good name. If they bring friends from the Jambi Malay ethnic group to a large Chinese family event, then some family members will give a strange look and whisper in the back to discuss the dislike of the presence of other ethnic groups at family events. The doctrine and 'entrusted experience' of parents have shaped informants' perceptions of other ethnic groups. Parents shape the social personality of their children before entering into real social life. Values such as original ancestral heritage should not be changed no matter what happens, which will then be a binding factor. The doctrine that their ethnicity is the best ethnic has created its boundaries in the process of communication between ethnic Chinese and Jambi Malay.

\section{B. Symbolic Interaction}

Social life is closely related to symbolic interactions. Symbolic interactions focus on the importance of forming meaning for human behavior. Symbolic interaction theory cannot be separated from the communication process, because initially, the meaning itself has no meaning, until it is finally constructed interpretively by individuals through the process of interaction, to create meaning that is mutually agreed upon (Nugroho, 2016).

In the process of interaction, meanings and symbols are created. These meanings and symbols make it possible for someone to perceive and view things differently from others. Symbolic interaction theory shapes communication behaviors. Behavior is goal-oriented. In other words, the behavior is generally motivated by the desire to obtain certain goals. Specific goals are not always known consciously by those concerned. The impetus that motivates individual behavior patterns that is manifest at certain levels is in the subconscious (Blanchard \& Hersey, 2004). Symbolic interaction theory focuses on individual analysis, especially the way individuals view themselves and their environment (Abidin \& Djabbar, 2019).

\section{Research Methodology}

This research is divided into two stages, the first stage: mapping merchants and buyers from ethnic Malay and Chinese by direct observation and interviews. Identification was carried out on groups of female merchants of ethnic Jambi Malay and Chinese. The second stage: exploring the social inequalities that occur between merchants and buyers of both ethnic groups and continues with drawing conclusions and recommendations in the management of social inequalities. This research conducted interviews and direct observation by visiting relevant informants and data deepening. This data collection is carried out several times to get the accuracy of the results. The entire research was conducted for six months. The research was conducted at Pasar Hong Kong located on Jalan Hayam Wuruk, Jelutung sub-district, Jambi city, which includes a shopping area for daily needs, specifically for the Chinese community in Jambi city.

This research was qualitative research with a case study approach. This approach is increasingly broad and as an important study because it can understand human communication 
behavior that is closely related to culture. A case study is an approach to analyzing a discourse that is used. Due to the scope of this method, case studies can be directed at a broad view of life and society. Case studies concentrate on a single phenomenon, individual, community, or institution, where the research aims to reveal the real interactions of significant factors that are characteristic of this phenomenon, individual, community, or institution (Berg \& Lune, 2011).

Research data obtained from 1) Primary data which included participant observation at the research location by observing conversations between sellers and buyers while making a transaction. This research identified the problem from two informants' perspectives, from the Malay and also Chinese side. This research also collected data through structured and unstructured interviews and make observations. 2) Secondary data: obtained from the results of previous studies such as theses or dissertations, journals, bulletins, magazines, books, newspapers, regulations, internet, and other supporting sources.

Information and required data in this research were explored in two ways, namely (1) determining the key person who was considered to know the initial information about the required data. (2) Using snowball sampling techniques, this research asks for referrals of informants who have strategic information related to the required data. Informants who are considered to have information about the object of research are sellers and buyers at Pasar Hong Kong.

The informants are determined based on the criteria, 1) the female merchants of ethnic Malay and Chinese are considered to have accurate information because the merchants know well the problems that occur; 2) the merchants and buyers of ethnic Malay and Chinese because they have experience and have interacted in the market, as well as 2 speakers from Malay and Chinese traditional leaders who are considered to have additional information for past problems and the present situation.

\section{Results and Discussion}

\section{A. The Dynamics of Social Inequality}

With a large number of ethnic Chinese, communication and interaction between ethnic Malay and Chinese is a routine of daily life. However, many differences were found in the daily communication of the two ethnic groups due to different cultural backgrounds and cultural values, which then influenced the attitudes and behavior of each ethnic group.

Almost all informants are bound to exist perceptions, which are not purely the result of their own experiences. Initially, it was the result of doctrine and then they applied it with the existence of intercultural communication among ethnic Chinese and Jambi Malay. The point is the assumption that the ethnic Chinese consider themselves to be an oppressed minority, whereas if traced, they are not a minority and they are also not oppressed. According to population census data in 2015, the population of Jambi Province was 3,397,164 people, and 42,124 people were ethnic Chinese. That is not the smallest ethnic population in Jambi province.

Negative assumptions among ethnic groups are kept private but continue to influence relations among the two ethnic groups. For example, the assumption that ethnic Chinese are true Chinese when consuming pork while the ethnic Jambi Malay, with a majority, are Muslim, forbid consuming pork. This will become an obstacle in the social life of the two ethnic groups which are domiciled in one region, and greatly affect the intercultural communication of the two ethnicities. "Chinese eat pork, forbidden food" will continue to exist and hinder communication between the two ethnicities.

The wrong perception and allowed to remain wrong, sometimes it is precisely linked and made up so that there is a correlation with a particular ethnicity. The ethnic Chinese has the 
perception that the ethnic Jambi Malay are lazy, blackmail, spree, and differentiate the ethnic Chinese and other migrants. Likewise, the ethnic Malay has the perception that the ethnic Chinese are workaholics, doing bribes to facilitate business, and consider themselves as ethnic minorities so that it is easier for the affairs of society. The perception that develops rapidly is precisely the perception that can happen to any individual and any ethnicity. However, it is always associated with one ethnic group, as if this is a characteristic of a particular ethnicity.

There is a tendency to use the standard values of their ethnicity to other ethnicities. Ethnicity is used as a benchmark for what is believed to be right and wrong. Values that are often compared to ethnicity are always made a necessity for other ethnicities. For example, ethnic Chinese are known as people who have the determination and desire to work hard, energetic, full of initiative and creative, especially in business. The ethnic Chinese will assume that other ethnic groups, such as the ethnic Jambi Malay, who are mostly ethnic Chinese employees, are the opposite of their ethnicity characteristic, which is lazy, only oriented towards money for daily life, and so on. The tendency of the ethnic Chinese community to force others must be following the description of the values they have which almost always aggravates the distance or gap in the process of intercultural communication among the two ethnicities.

Shifts and fusion of values are the results of education and technological progress. Interviews conducted with informants, ethnic Malay and Chinese, showed the same results. Individuals who have a fairly high level of education, equivalent to Senior High Schools have a fair open-mindedness to various cultural values in intercultural communication between ethnic Chinese and Jambi Malay. They are broad-minded, open and convey that they often adopt good values from ethnic groups outside of their ethnic groups. For example, the ethnic Jambi Malay appreciated the enthusiasm of work and care for the happiness of ethnic Chinese families. In line with that, the ethnic Chinese also like some characteristics of the ethnic Jambi Malay such as cooperation, being able to survive under pressure, and so on, which they encounter in daily lives.

Technological progress also plays an important role in shifting values that exist among the two ethnic groups. For example, some ethnic Chinese traditions in the preparation of marriage, according to the tradition of the ancestors must provide pig heads, 7-color yarn, chamber pots, clogs, and several other preparations that have begun to be abandoned. Because some opinions say that it can no longer be applied at this time, so that value is slowly abandoned. From the discussion above, this research can draw a common thread in intercultural communication that communication between humans is bound by culture, as cultures differ from one another so that the practices and communication behaviors of individuals based on culture will also be different. It can be said that humans learn to communicate and view their world through categories, concepts, and symbols caused by cultural influences. Also, it seems that each person from a different culture has a different view in positioning an object or situation, and vice versa.

Communication between humans is bound by culture, as culture differs from one another so that the practice and behavior of the communication of individuals built-in culture will also be different (Lubis, 2012). Intercultural communication is more likely to be known as cultural differences in perceiving social objects and events, where problems in communication occur due to differences in perception in viewing the problem itself.

In this case, intercultural communication is expected to play a role in multiplying and deepening similarities in individual perceptions and experiences. However, the character of culture tends to introduce us to different experiences, thus bringing us to different perceptions of our external world. Communication and culture have a reciprocal relationship, like two sides

Copyright (C 2020. Owned by Author(s), published by Society. This is an open-access article under the CC-BY-NC-SA license. https://doi.org/10.33019/society.v8i1.126 
of a coin. Without good communication, intensive communication, and communication using mass media, the dissemination of information, especially cultural information will be difficult to obtain. This situation has an unfavorable effect on cultural diversity and will facilitate the emergence of disagreements because of a lack of understanding that ultimately leads to conflict (Aminullah et al., 2015).

The social inequality among the ethnic Malay and Chinese can be felt especially when communicating in transactions, in the market between merchants and buyers. In symbolic interactions, Herbert Blumer explained that humans will respond and act on the meanings received and given by others. Some ethnic Malay merchants said that the different languages used by ethnic Chinese and Malay merchants also formed a grouping of buyers. This can be seen from the results of interviews with several informants who stated as follows:

"I have difficulty serving ethnic Chinese buyers because they prefer to speak Chinese, I don't understand". (Interview, Aritonah, Age 50)

"If buyers and sellers are both Chinese, they speak Chinese; most of them prefer shopping with fellow Chinese". (Interview, Alifendra, 56 years)

Observation results indicate that ethnic Chinese buyers prefer to conduct transactions with fellow ethnic Chinese because of the limited ability of the ethnic Malay female merchants to communicate using the Chinese language. But some ethnic Chinese buyers choose to make transactions with ethnic Malay female merchants.

If related to the transaction method, several informants said that conducting transactions with ethnic Malay made it more possible for the bargaining process, as stated by the following merchants:

"Ethnic Malay behaves stingy, likes to bargain, talkative and too many requests in the transaction process. But sometimes some Malay people are good at doing it". (Interview, Cici, 53 years old)

Similar things were said by other merchants:

"Malay people like to bargain, talkative, and make it complicated, different from Chinese people who understand each other. I rarely interact with Malay people who are my ethnicity, but basically, Malay people are good".(Interview, Suti, 50 Years old)

"In making transactions, Malay people are not talkative; it's the same with Chinese people. If they like it they will buy it. The difference is that usually Malay people prefer to bargain". (Interview, Santi, 37 years old)

From the results of the interview excerpts above, it appears that there is no social inequality among ethnic Malay and Chinese. But when conducting transactions, some ethnic Chinese merchants feel more comfortable doing transactions with fellow ethnic Chinese than ethnic Malay. Although they still serve buyers who are ethnically different from them.

The ethnic Chinese are a minority in the city of Jambi, but they make a large contribution in the economic field. The inequality that occurs is often due to stereotypical reasons that come from the two ethnicities. Stereotypic traditions occur from generation to generation because stereotypes have characteristics that are widely trusted with a group of individuals, both good 
and bad (Adyapradana, 2018). In Indonesia, the orientation of multiculturalism as an ideal concept, which has been clearly described by the slogan "Bhinneka Tunggal Ika" (Unity in Diversity) has not been able to accommodate ethnic Chinese as an integral part of Indonesia (Juditha, 2015).

Based on the results of data collection that have been done, it can be illustrated that they know and realize that ethnic groupings in their environment should not occur because it will lead to conflict. They always try to trade side by side, even though the majority of traders and buyers in this market are ethnic Chinese. In the interview results, it was also found that ethnic Chinese and Malay merchants were free to sell their wares to their interethnic buyers.

\section{B. Involvement of Traditional Leaders}

The city of Jambi has a variety of cultures because of its ethnic diversity. Ethnic Malay is strong in direct interaction with others and upholds their customs. Ethnic Malay always solves problems through deliberation led by a traditional leader.

Muchtar Agus Cholif, Deputy Chairperson of the Malay Customary Institution of Jambi Province, held the title of Adipati Cendikio Anggo Gantarajo, explained that the indigenous people of the city of Jambi did not look at their ethnicity when they lived in the city of Jambi. All tribes/ethnicities must still obey the Customary Law and must mingle with the community. There is no difference but mutual respect and tolerance must be upheld. Likewise with religious harmony in the city of Jambi which has a diversity of religions, but all of them are citizens of the city of Jambi and protected by Jambi customs. Ethnic Malay in the city of Jambi is strongly emphasized to do good to their parents, and friends or colleagues.

Muchtar Agus Cholif explained that there were no big obstacles when ethnic Chinese and Malay interacted although ethnic Chinese were more preoccupied with their activities in the trade so they did not have much time to communicate with other ethnic groups. The economic activities of the Chinese in Jambi are usually located in shophouses which also serve as residences for practical and efficient reasons (Karmela \& Pamungkas, 2017).

According to Muchtar Agus Cholif, their expertise and focus in trading made them seem closed and did not want to mingle with other ethnic groups, as stated in the following interview excerpt:

"There are no inhibiting factors; Chinese people are not like Malay people. They actively work to earn money, actively trade, have less time to communicate except for trade/business. So it is a factor that inhibits communication among ethnic Malay and Chinese". (Interview, Muchtar)

The establishment of the Malay Customary Institution was based on the Minister of Home Affairs Regulation No. 11 of 1979, which was expected to guide the customs of the city of Jambi to be maintained. Based on the Jambi Province Regional Regulation, the people who work in this institution must understand, practice and enforce Jambi Malay customary law.

Furthermore, Muchtar said that at this time, cultural and traditional values are getting loose because most people no longer know the meaning of shame when making a mistake. Moreover, there is no shame in berating and vilifying each other, even though in the Malay customs of the city of Jambi, it is strongly emphasized not to do such things.

The realization of peace and harmony is one of the requirements in avoiding conflict in society. That is why the government together with all components in society truly fosters and develops harmony in religious life (Harahap et al., 2017). 
The ethnic Chinese also have a very good relationship with other ethnic groups in the city of Jambi, including the ethnic Malay. They respect each other. Most of the people in Jambi city are Malay people. According to the informant of this research, Suhu Aguan (ethnic Chinese leader), said that there was no specific forum for meetings among ethnic Chinese and Malay. There is only the Forum Kerukunan Umat Bergama (Forum for Religious Harmony or FKUB), which consists of each religion.

Suhu Aguan explained that ethnic Chinese did not close themselves to the community. This is because most of the ethnic Chinese focus on business and work. They also don't interfere with other people's business. So when they interact with ethnic groups, it is limited to business matters, for example in terms of cooperation, opening shops, and employees who are mostly Malay people.

The involvement of traditional leaders in resolving conflicts between ethnic groups is very important according to Suhu Aguan, as the following quote:

"We as community leaders, we must act quickly, hold meetings to reach consensus. The meeting among ethnic leaders is very important; if there is a conflict it certainly harms us". (Interview, Suhu Aguan)

The involvement of traditional leaders in managing social inequality is very important due to the lack of assimilation among ethnic Chinese and Malay so that it seems individual. Furthermore as stated below:

"In my opinion, it is not much different, ethnic Chinese and Malay are the same as those who live rich and some live poor. Maybe there is a lack of assimilation. The lack of assimilation is the cause of inequality, if assimilation occurs, social inequality will no longer exist". (Interview, Suhu Aguan)

To establish a good relationship, Suhu Aguan suggested sharing among ethnic groups and avoiding the impression of stereotypes and discrimination, so they can live side by side.

"In social inequality, there is no real difference, for example, when we get the excess fortune, we often hold social services, not only for Chinese people but for everyone. This activity is routinely carried out every year to share with others". (Interview, Suhu Aguan)

It is not only traditional leaders, who play an important role in the implementation of customary values and good character, but family, friends, and the community become a very influential place in overcoming the social inequalities among the two ethnic groups.

\section{Conclusions}

Ethnic Chinese still feel the impression of discomfort or insecurity because they always position them as ethnic minorities. Concretely, there is no communication distance between the two cultures. But the difference is clear among the female merchants of ethnic Malay and Chinese when serving different ethnic buyers and merchants, for example in terms of the language used and the selling price offered. This is because the minority doctrine, that has been embedded since childhood and continues to descend to the next generation, overshadows the minds of the next generation of ethnic Chinese. The values of each ethnicity, which are still used as a basis for interacting with other ethnicities, still cause conflict, stereotypes, and friction in 
social inequalities that trigger and encourage inter-ethnic conflict. The involvement of traditional leaders is needed in minimizing the social inequalities that occur among ethnic Malay and Chinese, by inviting people to respect each other and to live side by side between ethnic groups. The traditional leaders act as social mediators by holding meetings among ethnic and inter-ethnic leaders to reach consensus so that inter-ethnic assimilation occurs and the assumption that ethnicity is better than other ethnic groups can be avoided.

\section{Acknowledgment}

The authors would like to thank the Directorate General of Research Strengthening and Development for support and facilities for making this research success through Beginner Lecturer Research Grant Scheme (Indonesian: Hibah Penelitian Dosen Pemula (044/L10/AK.04/Kontrak-Penelitian/2019)), awarded by the Ministry of Research, Technology and Higher Education of the Republic of Indonesia following Decree Number 7/E/KPT/2019. The authors also wish to thank all informants who have provided help and information during this research conducted.

\section{References}

Abidin, K., \& Djabbar, Y. (2019). A Symbolic Interaction Analysis of Waria (Transgender Women) in Makassar - Eastern Indonesia. Society, 7(2), 195-212. https://doi.org/10.33019/society.v7i2.113

Adyapradana, G. (2018). Identitas dan Pembentukan Stereotip Pemain Indonesia Dalam Online Game. Jurnal Komunikasi Indonesia, 4(2). https:/ / doi.org/10.7454/jki.v4i2.8884

Aminullah, A., Lestari, P., \& Tripambudi, S. (2015). Model Komunikasi Antarbudaya Etnik Madura dan Etnik Melayu. Jurnal ASPIKOM, 2(4), 272-281. https:/ / doi.org/10.24329/aspikom.v2i4.77

Badan Pusat Statistik Provinsi Jambi. (2016). Profil Penduduk Provinsi Jambi (Hasil SUPAS 2015). Retrieved from https://jambi.bps.go.id/: https:/ /jambi.bps.go.id/publication/2016/11/30/f37f899e8243431021fc2911/profilpenduduk-provinsi-jambi--hasil-supas-2015-.html

Berg, B. L., \& Lune, H. (2011). Qualitative Research Methods for the Social Sciences (Ninth Edition). Global Edition. New York, NY: Pearson Education Inc.

Blanchard, K. H., \& Hersey, P. (2004). Management Of Organizational Behavior: Utilizing Human Resources. Englewood Cliffs, New Jersey: Prentice-Hall.

Darmawan, K. Z. (2008). Penelitian etnografi komunikasi: tipe dan metode. Mediator: Jurnal Komunikasi, 9(1), 181-188. https:/ / doi.org/10.29313/mediator.v9i1.1142

Efnita, S., Taufik, T., \& Uyun, Z. (2007). Adversity quotient pada pedagang etnis Cina. Indigenous: Jurnal Ilmiah Psikologi, http://journals.ums.ac.id/index.php/indigenous/article/view/4714

Harahap, B., Nasution, H., \& Kholil, S. (2017). Pola Komunikasi Tokoh Agama dan Tokoh Adat dalam Meningkatkan Keharmonisan Hubungan Antarumat Beragama di Kecamatan Pintu Pohan Meranti Kabupaten Toba Samosir. Al-Balagh: Jurnal Komunikasi Islam, 2(2), 220-231. http://jurnal.uinsu.ac.id/index.php/balagh/article/view/1469

Juditha, C. (2015). Stereotip dan Prasangka dalam Konfl ik Etnis Tionghoa dan Bugis Makassar. Jurnal ILMU KOMUNIKASI, 12(1). https:/ / doi.org/10.24002/jik.v12i1.445 
Karmela, S. H., \& Pamungkas, S. (2017). Kehidupan Sosial Ekonomi Orang-orang Tionghoa Di Kota Jambi. Jurnal Ilmiah Dikdaya, 7(1), 55-62. http://dikdaya.unbari.ac.id/index.php/dikdaya/article/view/30

Lampe, I., \& Anriani, H. B. (2016). Stereotipe, Prasangka dan Dinamika Antaretnik. Jurnal Penelitian Pers dan Komunikasi Pembangunan, 20(1), 19-32. http://jurnalp2kp.id/index.php/jp2kp/article/view/42

Lubis, L. A. (2012). komunikasi antar budaya etnis tionghoa dan pribumi di kota Medan. Jurnal $\begin{array}{llll}\text { Ilmu Komunikasi, } & \text { 10(1), 13-27. }\end{array}$ http://jurnal.upnyk.ac.id/index.php/komunikasi/article/view/83

Nugroho, O. (2016). INTERAKSI SIMBOLIK DALAM KOMUNIKASI BUDAYA (Studi Analisis Fasilitas Publik Di Kabupaten Ponorogo). ARISTO, 3(1), 1 - 18. http:/ / dx.doi.org/10.24269/ars.v3i1.7

Reinhard, S. (2014). Gambaran Etos Kerja Pada Pedagang Etnis Tionghoa di Jakarta. Psibernetika, 7(1), 65-78. https://journal.ubm.ac.id/index.php/psibernetika/article/view/510

Rodriguez-Bailon, R., Bratanova, B., Willis, G. B., Lopez-Rodriguez, L., Sturrock, A., \& Loughnan, S. (2017). Social class and ideologies of inequality: How they uphold unequal societies. Journal of Social Issues, 73(1), 99-116. https://doi.org/10.1111/josi.12206

Samovar, L. A., Porter, R. E. dan McDaniel, E. R., (2014). Komunikasi Lintas Budaya (Translated). Jakarta: Salemba Humanika.

\section{About the Authors}

1. Eraskaita Ginting, obtained her Magister Degree from Padjadjaran University, Bandung, Indonesia, in 2012. The author is an Assistant Professor at the Department of Communication Studies, Faculty of Social and Political Sciences, Raden Fatah State Islamic University of Palembang, Indonesia.

E-Mail: eraskaitaginting_uin@radenfatah.ac.id

2. Yusnaini, obtained her Magister Degree in from Mercu Buana University, Jakarta, Indonesia, in 2014. The author is an Assistant Professor at the Department of Communication Studies, Faculty of Social and Political Sciences, Nurdin Hamzah Institute of Social and Political Sciences, Indonesia.

E-Mail: yusnaini.oke@gmail.com 